Available online at GSC Online Press Directory

GSC Biological and Pharmaceutical Sciences

e-ISSN: 2581-3250, CODEN (USA): GBPSC2

Journal homepage: https://www.gsconlinepress.com/journals/gscbps

(RESEARCH ARTICLE)

\title{
The antispasmodic activity of ethanol extract of the stem bark of Piliostigma reticulatum Horscht D.C (Ceasalpiniaceae), and its dichloromethane fraction isolated
}

\author{
Dosso Kassim 1, ${ }^{*}$, Gboko Abiba Ouattara ${ }^{2}$, Attemene Dago Serge David ${ }^{1}$, N'guessan Banga Benoit ${ }^{3}$ and Yapo \\ Angoue Paul 4 \\ ${ }^{1}$ Laboratory of Physiology and Pharmacology, UFR Environment, University of Jean Lorougnon Guédé of Daloa, P.O 02 \\ Box 150 Daloa 02, Daloa, Côte d'Ivoire. \\ ${ }^{2}$ Laboratory of Biotechnology in agro-resources valorization and natural substances, UFR Biological Sciences, University \\ of Korhogo, P.O Box 1328 Korhogo, Korhogo, Côte d'Ivoire. \\ ${ }^{3}$ Department of Pharmacology and Toxicology, School of Pharmacy, College of Health Sciences, University of Ghana, P.O \\ Box KB 52, Korle-Bu, Accra, Ghana. \\ ${ }^{4}$ Laboratory of Physiology and Pharmacology, UFR Natural Sciences, University of Nangui Abrogoua, 01 P.O Box 801 \\ Abidjan 01, Abidjan, Côte d'Ivoire.
}

Publication history: Received on 25 February 2020; revised on 02 April 2020; accepted on 04 April 2020

Article DOI: https://doi.org/10.30574/gscbps.2020.11.1.0049

\begin{abstract}
Piliostigma reticulatum (Caesalpiniaceae) has been used in traditional medicine for the treatment of gastrointestinal disorders like diarrhea. The aim of the present study was to examine the relaxant activity of an extract of $P$. reticulatum stem bark and five of its fractions on isolated rabbit duodenum. Segments of duodenum of rabbits were suspended in an organ bath. The ethanol extract had been fractioned to obtain some fractions heptane, dichloromethane, ethyl acetate, butanol and aqueous extract. The ethanol extract and the dichloromethane fraction were tested on the contraction of rabbit duodenum at the increasing concentrations. Increasing concentrations of $P$. reticulatum ethanol extract and its fraction induced a relaxant effect on spontaneous rabbit duodenum. The ethanol extract reduced duodenum contraction totally at $1.32 \mathrm{mg} / \mathrm{mL}$ at $\mathrm{IC}_{50}=0.62 \mathrm{mg} / \mathrm{mL}$. At the test concentration of $0.52 \mathrm{mg} / \mathrm{mL}$ in organ bath, the dichloromethane fraction showed a relaxation of $100 \%\left(\mathrm{IC}_{50}=0.24 \mathrm{mg} / \mathrm{mL}\right)$. Piliostigma reticulatum stem bark possesses antispasmodic properties that can at least explain and support its traditional use against diarrhea.
\end{abstract}

Keywords: Antispasmodic activity; Piliostigma reticulatum; Gastrointestinal disorders.

\section{Introduction}

Treatment of spastic motility disorders continues to be challenging. Therapeutic options remain limited due in part to our lack of understanding of the pathophysiology and significance of these disorders [1]. Antispasmodics are drugs used to relieve or prevent smooth muscle spasms. By reducing the intestinal hyper-contractility of smooth muscles, these drugs allow the gastrointestinal muscle to return to their proper tone, therefore reducing many of abdominal pains and symptoms [2]. Hence, antispasmodics are frequently prescribed for a number of gastrointestinal diseases, including irritable bowel syndrome, a condition which affects $10-25 \%$ of the general population [3]. Main antispasmodic drugs include anti-muscarinic compounds (e.g. the alkaloids derived from the plant belladonna and their synthetic derivatives) and calcium channel blockers (e.g. otilonium and pinaverium) [3,4]. Since, the use of these drugs may be associated with the appearance of unwanted side effects like dry mouth and urinary retention for anti-muscarinic drugs, and headache, nausea, vomiting and constipation for calcium blockers. Thus, the search of safe, plant-derived antispasmodics becomes a challenging option.

\footnotetext{
* Corresponding author: Dosso Kassim kassdoss02@yahoo.fr, +22549935642 / 05451630
} 
Some medicinal plant species are used in traditional medicine for the treatment of gastrointestinal disorders including diarrhea, indigestion and constipation $[5,6,7,8]$. Scientific investigations using different pharmacological tests are performed to prove their potential efficiency. Evaluation of antispasmodic activity on some isolated organs has demonstrated that some of these medicinal plant species possess significant and interesting spasmolytic activity $[9,10$, 11] or spasmogenic activity [12]. In some cases, mechanisms concerning the antispasmodic activity of tested extracts are also reported $[12,13]$. Extensive investigations of active antispasmodic extracts have led to the isolation of active compounds belonging to different phytochemical groups $[14,15,16,17,18]$.

Piliostigma reticulatum which is found in tropical forests of West African countries like Côte d'Ivoire, Mali and Burkina Faso is traditionally used against many disorders like ulcers [19], boils, wounds, syphilitic cancer [20] and diarrhea [21]. The antidiarrheal activity of this specie has been demonstrated by [22] and [23]. Others studies have been realized like the anti-secretory activity [24], the anti-bacterial activity [25] and the toxicity [26].

The antispasmodic property of this plant has not yet been investigated veritably to our knowledge to show that this plant inhibits diarrhea by reduction of intestinal contraction. However, chemical compounds isolated from $P$. reticulatum like flavonols (6-C-methylquercetin-3-methyl ether-5; 6,8-di-C-methylkaempferol-3-methyl ether-6 and 6C-methylquercetin-3,3',7-trimethyl ether-7) and oxychromonol (6-C-methyl-2-p-hydroxyphenyloxychromonol, called piliostigmol) have been shown to exhibit antimicrobial activities against bacteria (Escherichia coli and Bacillus subtilis) and fungi (Aspergillus niger and candida albicans) which cause infectious diarrheas [25]. We have chosen dichloromethane fraction because this fraction showed an important antidiarrheal activity [23] and antibacterial activity [25] in our previous studies. The aim of this research was to separate different fractions of total hydro-alcoholic extract of $P$. reticulatum and, screen for their spasmolytic activity of the total extract and its dichloromethane fraction and, as well as to screen its phytochemical constituents.

\section{Material and methods}

\subsection{Plant material}

Stem barks of Piliostigma reticulatum (DC.) Horscht (Ceasalpiniaceae) were collected in Abidjan (South region of Côte d'Ivoire) in October 2018. The plant was identified and authenticated by the National Centre of Floristic of University of Cocody-Abidjan of Pr AKE Assi Laurent. A voucher specimen ( $\mathrm{N}^{\circ}$ 18033) of the plant has been deposited in the herbarium of this Centre.

\subsection{Preparation of the ethanol extract}

Stem barks of Piliostigma reticulatum were washed with distilled water, cleaned, cut into smaller pieces and kept at room temperature for two weeks. Then they were ground into a fine powder. The powder (100 g) was extracted with 2 liters of a solution of ethanol (96\%) / water (80:20) for 24 hours under constant stirring (this operation was repeated twice). The extract was filtered twice through cotton wool, then through Whattman filter paper $\left(\mathrm{N}^{\circ} 1\right)$. The filtrate was evaporated to dryness using a rotavapor (Buchi R110/NKE6540/2) at $45^{\circ} \mathrm{C}$, and dried under reduced pressure. Percentage yield was found to be $14.4 \%$.

Five liquid fractions (heptane, dichloromethane, ethyl acetate, butanol and aqueous) were extracted from the total extract by using successive liquid-liquid extraction [27].

\subsection{Animals}

Healthy rabbits (weighing 1.5-1.8 kg) of both sexes provided from UFR Biosciences (University of Cocody-Abidjan, Côte d'Ivoire) were used. They were kept and maintained under standard laboratory conditions of temperature one week before the experiments. The animals were fed with commercial pelleted diet (Ivograin ${ }^{\circledR}$, Abidjan, Côte d'Ivoire) and were given water ad libitum. They were deprived of food and for at least $24 \mathrm{~h}$ prior to experiments. The equipment, handing and sacrificing of the animals were in accordance with the European Council legislation 87/609/EEC for the protection of experimental animals [28].

\subsection{Smooth muscle preparation}

The experiments were carried out according to the Magnus general technique [29]. The animals were killed by decapitation and the duodenum was removed. A two $\mathrm{cm}$ long segment of the duodenum was suspended in $150 \mathrm{~mL}$ organ bath containing Tyrode's solution of the following composition (mM): $\mathrm{NaCl} 136.89, \mathrm{KCl} 2.68, \mathrm{CaCl}_{2} 1.80, \mathrm{MgCl}_{2} 1.05$, $\mathrm{NaHCO}_{3} 11.90, \mathrm{NaHPO}_{4} 0.42$ and glucose 5.55 , maintained at $37{ }^{\circ} \mathrm{C}$. The solution was aerated with a mixture of $95 \% \mathrm{O}_{2}$ 
and $5 \% \mathrm{CO}_{2}$.under a resting tension of $1 \mathrm{~g}$. The preparations were connected to transducer coupled to the graph paper. The suspended duodenum was allowed to equilibrate for $30 \mathrm{~min}$. The smooth muscles relaxant action of test materials was observed by administration of extracts [30]. The bath was washed after testing each concentration of extracts.

The inhibition of duodenum contraction by test sample was expressed as percentage of mean \pm SEM from six experiments in the presence of extracts and was calculated using the following formula:

$$
\% \text { Inhibition }=\frac{A-B}{A} \times 100
$$

Where $\mathrm{A}$ is the amplitude $(\mathrm{cm})$ of the normal duodenum contraction and $B$ the amplitude (cm) of the duodenum contraction induced by the extracts in the presence of the test sample [31].

To determine $\mathrm{IC}_{50}$ values, crude extracts and fractions were tested at different concentrations from 0.13 to $1.32 \mathrm{mg} / \mathrm{ml}$ (twofold dilution) in organ bath respectively. The IC $_{50}$ value of each sample was derived from the sigmoid doseresponse curves.

\subsection{Phytochemical screening}

The extract was screening for the presence of tannins, flavonoids, alkaloids, sterols, saponins, polyphenols, polyterpenes and quinons. Detection of these constituents was carried out as described by [32].

\subsection{Statistical analysis}

The results were expressed as mean \pm SEM. Data were analyzed for statistical significance by one-way ANOVA followed by Tukey test using the GraphPad Demo 5 (San Diego). At $95 \%$ confidence interval p $<0.05$ was considered as statistically significant.

\section{Results}

\subsection{Extraction of plant material}

The amount of total ethanol extract was $14.4 \%$. From dried ethanol extract (starting with 10 g), heptane (90 mg; 3.6 $\%$ ), dichloromethane (200 mg; 8 \%), ethyl acetate (500 mg; $20 \%$ ), butanol (700 mg; $28 \%$ ) and aqueous (900 mg; 36 $\%)$.

\subsection{Antispasmodic activity of ethanol extract}

Rabbit duodenum suspended in tyrode's solution under $1 \mathrm{~g}$ tension after $30 \mathrm{~min}$ had a stable tension. The doses of 0.13 and $0.26 \mathrm{mg} / \mathrm{mL}$ product any effect on duodenum contraction. At doses of $0.52 ; 0.79$ and $1.04 \mathrm{mg} / \mathrm{mL}$ (significantly reduced), the contraction was reduced respectively to 21; 84 and $94 \%$ (Table 1). The contraction of duodenum was totally and significantly inhibited at $1.32 \mathrm{mg} / \mathrm{mL}$ (n=6; Figure 1). The IC50 was $0.66 \mathrm{mg} / \mathrm{mL}$ (Figure 2).

Table 1 Effects of ethanol extract of $P$. reticulatum on duodenum contractions in rabbits.

\begin{tabular}{ll}
\hline Concentrations & Inhibition of contraction \\
\hline $0.26 \mathrm{mg} / \mathrm{mL}$ & $0 \pm 0$ \\
$0.52 \mathrm{mg} / \mathrm{mL}$ & $21 \pm 0.66$ \\
$0.79 \mathrm{mg} / \mathrm{mL}$ & $84 \pm 0.94$ \\
$1.04 \mathrm{mg} / \mathrm{mL}$ & $94 \pm 1.84^{*}$ \\
$1.32 \mathrm{mg} / \mathrm{mL}$ & $100 \pm 0^{* *}$ \\
\hline \multicolumn{1}{c}{ Values are the mean $\pm \operatorname{SEM}(\mathrm{n}=6) ;{ }^{*} \mathrm{p}<0.05^{* *} \mathrm{p}<0.001}$.
\end{tabular}



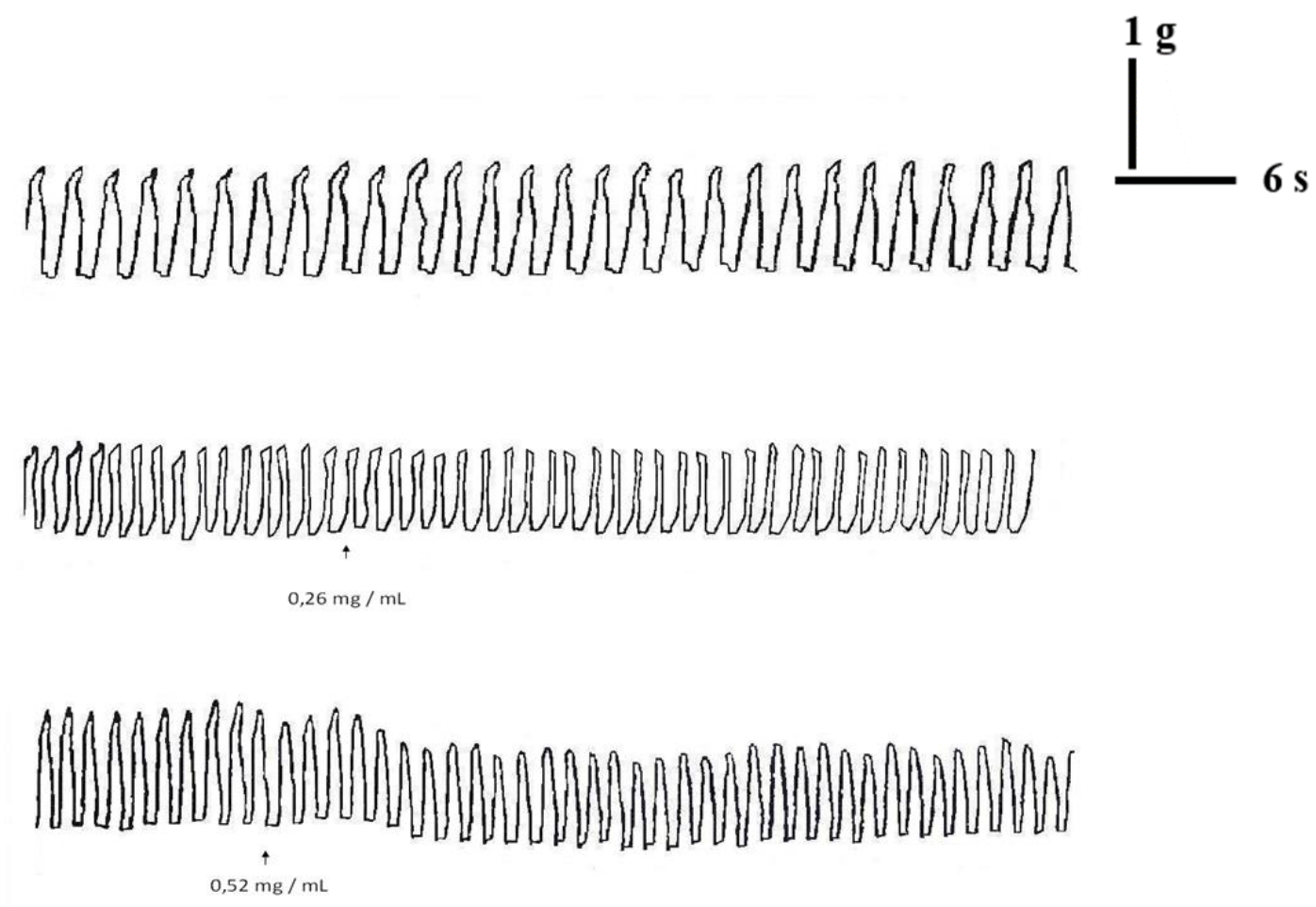

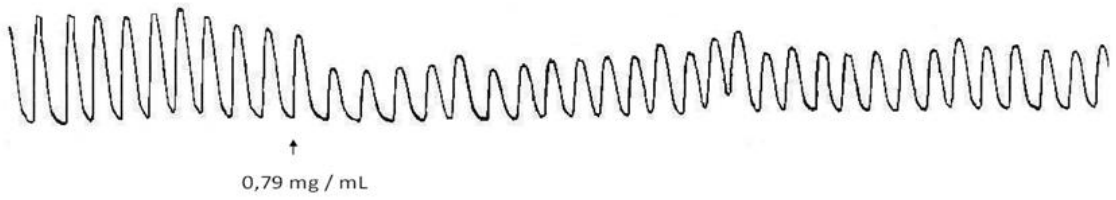

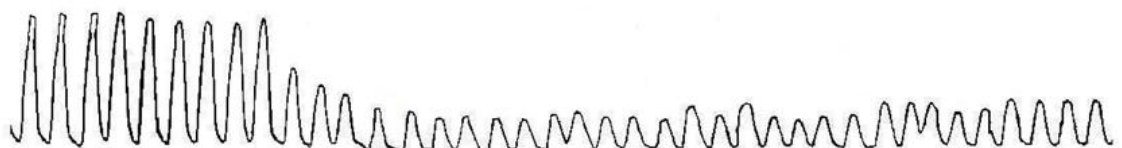
$1,04 \mathrm{mg} / \mathrm{mL}$

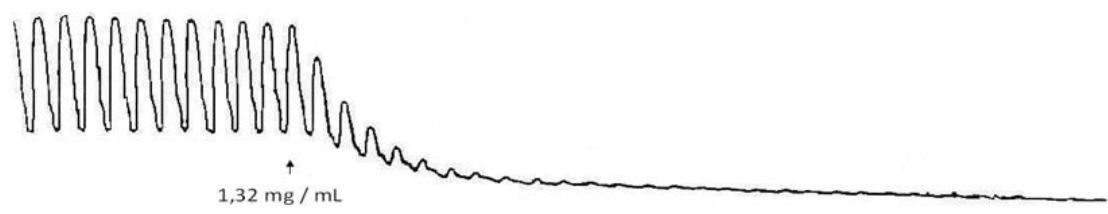

Figure 1 Effect dose-response of crude ethanol extract $(A=$ normal contraction). 


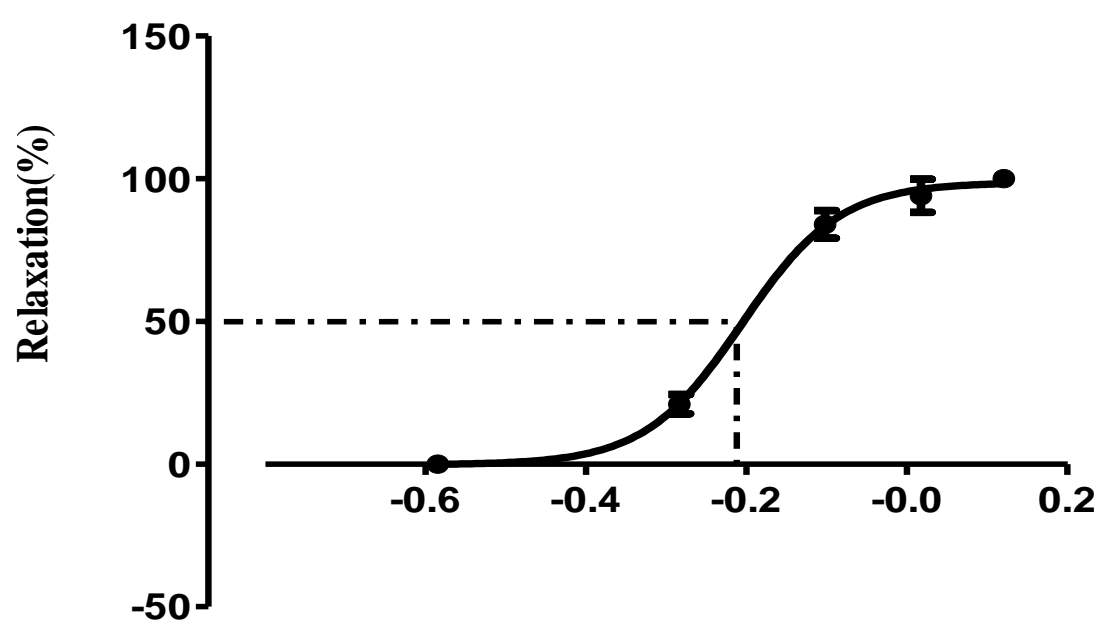

\section{Log $[$ concentration $(\mathbf{m g} / \mathbf{m L})]$}

Figure 2 Sigmoid curve of ethanol extract effect.

\subsection{Antispasmodic activity of dichloromethane fraction}

At $0.13 \mathrm{mg} / \mathrm{mL}$ the extract reduced lightly duodenum contraction at $15 \%$ (Table 2). But at $0.26 ; 0.39$ and $0.52 \mathrm{mg} / \mathrm{mL}$, the relaxation was significantly and strongly observed ( $\mathrm{n}=6$; Figure 3). The IC $\mathrm{C}_{50}$ was $0.24 \mathrm{mg} / \mathrm{mL}$ (Figure 4). The percentages of inhibition were $65 \%$ for $0.26 \mathrm{mg} / \mathrm{mL}, 96 \%$ for $0.39 \mathrm{mg} / \mathrm{mL}$, and $100 \%$ for $0.52 \mathrm{mg} / \mathrm{mL}$ (Table 2).

Table 2 Effects of dichloromethane fraction on duodenum contractions in rabbits.

\begin{tabular}{ll}
\hline Concentrations & Inhibition of contraction \\
\hline $0.13 \mathrm{mg} / \mathrm{mL}$ & $15 \pm 1.30$ \\
$0.26 \mathrm{mg} / \mathrm{mL}$ & $65 \pm 2.12^{*}$ \\
$0.39 \mathrm{mg} / \mathrm{mL}$ & $96 \pm 0.54^{* *}$ \\
$0.52 \mathrm{mg} / \mathrm{mL}$ & $100 \pm 0^{* *}$ \\
\hline \multicolumn{2}{c}{ Values are the mean $\pm \operatorname{SEM}(\mathrm{n}=6) ;{ }^{*} \mathrm{p}<0.05 ;{ }^{* *} \mathrm{p}<0.001}$.
\end{tabular}



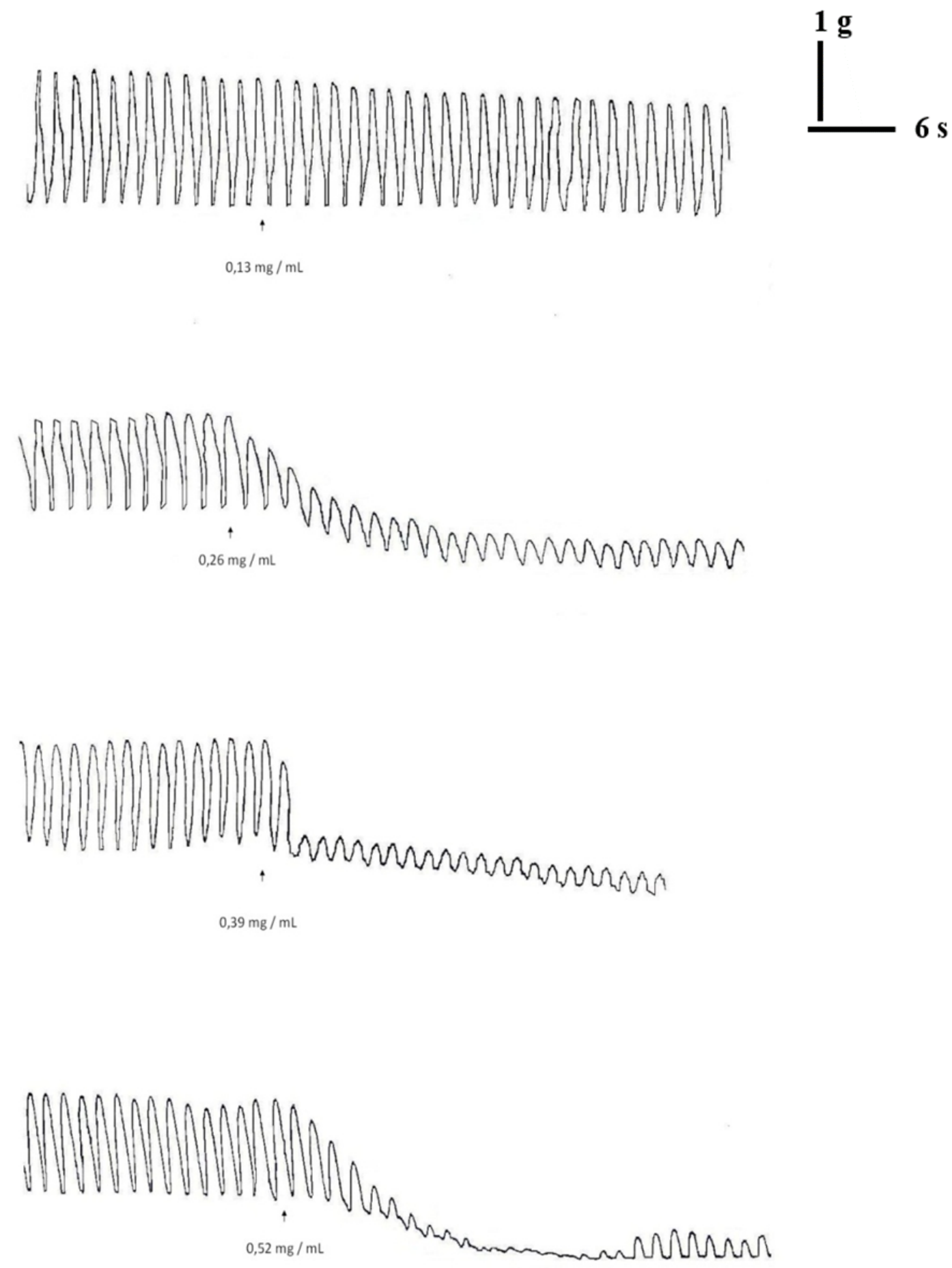

Figure 3 Effect dose-response of dichloromethane extract ( $A=$ =normal contraction). 


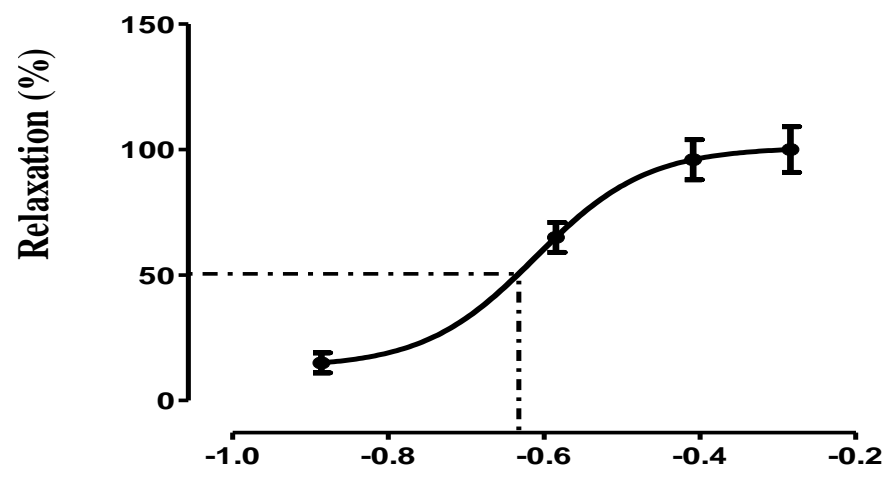

Log [concentration $(\mathbf{m g} / \mathbf{m L})]$

Figure 4 Sigmoid curve of dichloromethane extract effect.

\subsection{Phytochemical screening of dichloromethane fraction}

Phytochemical screening tests of dichloromethane fraction for various constituents revealed the presence of major components such as tannins and flavonoids. Polyphenols and reducing sugars were present, and anthraquinones, alkaloids, coumarins, polyterpenes and sterols were absent (table 3).

Table 3 Phytochemical screening of dichloromethane fraction and ethanol total extract of stem bark of P. reticulatum.

\begin{tabular}{ll}
\hline chemical constituents & Piliostigma reticulatutum \\
\hline Polyphenols & + \\
Sterols et polyterpernes & - \\
Flavonoids & ++ \\
Saponins & - \\
Tannins & ++ \\
Alkaloids & - \\
Quinons & - \\
Reducing sugars & + \\
Coumarins & - \\
\hline
\end{tabular}

$(-)$ absence, $(+)$ presence, $(++)$ major chemical constituents.

\section{Discussion}

The present study sought to assess the antispasmodic activity of Piliostigma reticulatutum. This plant was ethnobotanically selected during a survey ruled in 2018 in the City of Abidjan (Côte d'Ivoire) and realized through the actors of Ivorian traditional medicine including 8 herbalists and 1 healer. The results of the survey (data not shown) have allowed us to collect 17 antidiarrheal plant species among which Piliostigma reticulatutum was much advised for gastrointestinal disorders.

The objective of this work was to further investigate the antispasmodic effect of dichloromethane fraction of P.reticulatum and compare to the total extract effect to find out which is effective.

Our study showed that ethanol extract stem bark of $P$. reticulatum significantly inhibited the duodenum contraction, as shown by the figures. Also the dichloromethane fraction reduced significantly duodenum contraction. The relative potential action of the dichloromethane, indicate it contains constituents which are responsible for the inhibitory action of $P$. reticulatum on duodenum. The comparison of dose ratios $(\mathrm{x}=0.24 \mathrm{mg} / \mathrm{mL})$ at $\mathrm{IC}_{50}$ points shows that dichloromethane-rich fraction is more potent than the ethanol extract $(\mathrm{x}=0.66 \mathrm{mg} / \mathrm{mL})$. The dichloromethane extract have a better potency action on duodenum contraction in rabbits. 
Antispasmodic agents are considered useful for the treatment of pains resulting from spasms of the gut and diarrhea due to the hypermobility of the gastrointestinal tract $[12,33]$. Diarrhea mechanisms are various and involve often gastrointestinal disorders. Therefore we can assume that the antidiarrheal action of $P$. reticulatum could be mediated in by a mechanism involving the decrease of gastrointestinal mobility which results of inhibition of duodenum contraction.

The phytochemical screening of stem bark of $P$. reticulatm showed that tannins and flavonoids are the major components while polyphenols and reducing sugars were minors. The result also showed the absence of sterols, polyterpenes, saponins, alkaloids, quinons, and coumarins. These components observed could be responsible of antispasmodic activity of dichloromethane fraction and ethanol total extract of stem bark of $P$. reticulatum. Our results are in consonance with many studies in the literature. It was reported that flavonoids, [9, 34]; tannins, reducing sugars [35], were responsible of antispasmodic properties of certain plants like Pynocycla spinosa and Morinda morindoides.

The antispasmodic activity of flavonoids has been demonstrated and attributed to their ability to inhibit gastrointestinal mobility [36, 37]. In vitro experiments on animals have shown that flavonoids are able to inhibit the contractions induced by spasmogens [38, 39].

The antispasmodic activity of $P$. reticulatum could therefore due be to the presence of flavonoids, tannins, polyphenols and reducing sugars containing in dichloromethane fraction.

\section{Conclusion}

From this study, it can be concluded that the dichloromethane fraction which has been isolated in the total extract of $P$. reticulatum, contains an important antispasmodic activity. The mechanism action could be study by antagonism method with acetylcholine, propranolol and prazosin. It is suggested that the antispasmodic constituents must be isolated in order to identify the most active chemical substance, which could then be used possibly as an antispasmodic in gastrointestinal disorders such as diarrhea.

However, further bioassay-guided fractionation studies are required to identify the active principle (s) and their mechanism of action. Moreover, the use of aerial parts of the plant could be a solution to the utilization of its roots, therefore limiting the biodiversity degradation.

\section{Compliance with ethical standards}

\section{Acknowledgments}

This project was supported in part by the Non-government-organization for promotion of scientific research in African traditional medicine (NGO "PRORESMAT"). The authors wish to thank the National Centre of Floristic, University of Felix Houphouet Boigny of Professor AKE-ASSI Laurent for botanical identification of the plant. Also, we express our gratitude to Professor YAPO Angoue Paul, director of physiology and pharmacology laboratory of University of Nangui Abrogoua, for manipulations.

\section{Disclosure of conflict of interest}

The authors declare no conflict of interest.

\section{Statement of ethical approval}

If studies involve use of animal/human subject, authors must give appropriate statement of ethical approval. If not applicable then mention 'The present research work does not contain any studies performed on animals/humans subjects by any of the authors'.

\section{References}

[1] Achem SR. (2004).Treatment of spastic esophageal motility disorders. Gastroenterology Clinics of North America, $3,107-124$.

[2] Hasler WL. (2003). Pharmacotherapy for intestinal motor and sensory disorders. Gastroenterology Clinics of North America, 32, 707-732. 
[3] Farhadi A, Bruninga K, Fields J and Keshavarzian A. (2001). Irritable bowel syndrome: an update on therapeutic modalities. Expert Opinion Investigation Drug, 10, 1211-1222.

[4] Pasricha PJ. (2001). Prokinetic agents, antiemetics and agents used in irritable bowel syndrome. In: Hardman, J.G., Limbird, L.E., Goodman Gilman, A. (Eds.). Goodman \& Gilman's the Pharmacological Basis of Therapeutics. McGraw Hill, New York, 1021-1036.

[5] Borrelli F, Borbone N, Capasso R, Montesanoc D, De Marino S, Aviello G, Aprea G, Masone S and Izzo AA. (2009). Potent relaxant effect of a Celastrus paniculatus extract in the rat and human ileum. Journal of Ethnopharmacology, 122, 434-438.

[6] Valiollah H, Sadraei H, Ghannadi AR and Mohseni M. (2000). Antispasmodic and anti-diarrheal effect of Satureja hortensis L. essential oil. Journal of Ethnopharmacology, 71, 187-192.

[7] Kumar VL and Shivkar YM. (2004). In vivo and in vitro effect of latex of Calotropis procera on gastrointestinal smooth muscles. Journal of Ethnopharmacology, 93, 377-379.

[8] Ragone MI, Sella M, Conforti P, Volonté MG and Consolini AE. (2007). The spasmolytic effect of Aloysia citriodora Palace (Souch American cedrón) is partially due to its vitexin but not isovitexin on rat duodenums. Journal of Ethnopharmacology, 133, 258-266.

[9] Sadraei H, Asghari G and Hekmatti AA. (2003). Antispasmodic effect of three fractions of hydroalcoholic extract of Pycnocycla spinosa. Journal of Ethnopharmacology, 86, 187-190.

[10] Cortés AR, Delgadillo AJ, Hurtado M, Diminguez-Ramirez AM, Medina JR and Aoki K. (2006). The antispasmodic activity of Buddleja scordioides and Buddleja perfoliata on isolated intestinal preparations. Biological and Pharmaceutical Bulletin, 29, 186-190.

[11] Cechinel-Filho V, Zampirolo JA, Stulzer H and Schlemper V. (2007). Antispasmodic effects of Persea cordata bark fractions on guinea pig ileum. Fitoterapia, 78, 12-128.

[12] Gilani AH, Bashir S, Jambaz KH and Shah AJ. (2005). Presence of cholinergic and calcium channel blocking activities explains the traditional use of Hibiscus rosasinensis in constipation and diarrhea. Journal of Ethnopharmacology, 102, 289-294.

[13] Gilani AH, Kan A, Ali T and Ajmal S. (2008). Mechanisms underling the antispasmodic and bronchodilatory properties of Terminalia bellerica fruit. Journal of Ethnopharmacology, 166, 528-538.

[14] Abdalla S, Abu M and Sabri S. (1994). Effects of the flavone luteolin, isolated from Colchicum richii, on guinea-pig isolated ileum smooth muscle and heart on blood pressure and blood flow. Phytotherapy Reseach, 8, 265-270.

[15] Bergendorff O and Sterner O. (1995). Spasmolytic flavonoids from Artemisis abrotanum. Planta Medica, 61, 370371.

[16] Rojas A, Cruz PM and Mata R. (1995). Smooth muscle relaxant compounds from Dodonea viscosa. Planta. Medica, 62, 154-159.

[17] Rojas A, Cruz S, Ponce-Monter H and Mata R. (1996). Smooth muscle relaxing compounds from Dodonaea viscosa. Planta Medica, 62, 154-159.

[18] Trute A, Gross J, Mutschler E and Nahrstedt A. (1997). In vitro antispasmodic compounds of the dry extract obtained from Hedera helix. Planta Medica, 63, 125-129.

[19] Salawu OA, Tijani AY, Obidike IC, Rafindadi H and Emeje M. (2009). Anti-ulcerogenic properties of methanolic root extract of Piliostigma reticulatum (DC) Hoechst (Syn. Bauhinia reticulate DC) -Leguminosae in rats. African Journal of Pharmacy and Pharmacology, 3 (5), 252-258.

[20] Aderogba MA, Okoh EK, Adelanwa TA and Obuotor EM. (2004). Antioxidant properties of Nigerian Piliostigma species. Journal of Biology and Sciences, 4 (4), 501-503.

[21] Yelemou B, Bationo B, Yameogo G and Millogo-Rasolodimby J. (2007). Bois et Forêts des tropiques. Coden, 291, 55-66.

[22] Salawu SO, Tijani AY, Obidike IC and Chindo BA. (2007). Evaluation of anti-diarrhoeal properties of methanolic Root extract of Piliostigma reticulatum in rats. Journal of Phytomedicine Therapeutics, 12.

[23] Dosso K, N'guessan BB, Bidie AP, Gnangoran BN, Méité S, N'guessan D, Yapo AP and Ehilé EE. (2012). Antidiarrhoeal activity of an ethanol extract of the stem bark of Piliostigma reticulatum (Caesalpiniaceae) in rats. African Journal of Traditional Complementary and Alternative Medicine, 9 (2), 242-249. 
[24] Dosso K, N'guessan BB, Amoateng P and Gnangoran BN. (2012). Anti-secretory effects of a dichloromethane fraction of stem bark of Piliostigma reticulatum (Cesalpiniaceae). Journal of Medical and Biomedical Sciences, 1 (3), 13-20.

[25] N'guessan BB, Dosso K, Gnangoran BN, Amoateng B, Asiedu-Gyekye IJ and Yapo AP. (2015). Antibacterial and antispasmodic activities of a dichloromethane fraction of an ethanol extract of stem bark of Piliostigma reticulatum. Journal of Pharmacy and BioAllied Sciences, 7 (2), 128-135.

[26] Dosso K, N'guessan BB, Gnangoran BN and Yapo AP. (2014). Acute toxicity effects of dichloromethane fraction of ethanol extract of stem bark of Piliostigma reticulatum on rats. African Journal of Plant Science, 8(8), 405-409.

[27] Samsam-Shariat SH. (1992). Qualitative and Quantitative Evaluation of the Active Constituents and Control Methods for Medical Plants. Mani Publications, Isfahan, 23-30.

[28] Mitjans M, Garcia L, Marrero E and Vinardell MP. (2008). Study of ligmed-A, an antidiarrheal drug based on liguin, on rat small intestine enzyme activity and morphometry. Journal of Veterinary Pharmacology and Therapeutics, $24,349-351$.

[29] Magnus R. (1904). Persuche am überbunden Dünndarm Yon Saugetieren. Archives of Gesamte and Physiology, 102-123.

[30] Perry WLM. (1968). Pharmacological Experiments on Isolated Preparations. E \& S Livingstone Ltd (Edition 4), Edinburgh.

[31] Tona L, Kambu K, Mesia K, Cimanga K, Bruyne T, Pieters L, Totté J and Vlietinck AJ. (1999). Biological screening of traditional preparations from some medicinal plants used as antidiarrhoeal in Kinshasa, Congo. Phytomedicine, 6, 59-66.

[32] Békro Y, Bekro J, Boua BB, Tra Bi F and Ehile EE. (2007). Etude ethnobotanique et screening phytochimique de Caesalpinia benthamiana (Baill.) Herend et Zarrucchi (Caesalpiniaceae). Sciences de la Nature, 4 (2), 217-225.

[33] Crema Ponti FD. (1989). Recent advances in the physiology and pharmacology of intestinal motility. Pharmacology Research, 21, 67-73.

[34] Capasso A, Pinto A, Sorrentino R and Capasso F. (1991). Inhibitory effects of quercetin and other flavonoids electrically-induced contractions on guinea-pig isolated ileum. Journal of Ethnopharmacology, 34, $279-281$.

[35] Zaku SG, Abdulrahaman FA, Onyeyili PA, Aguzue 0 and Thomas SA. (2009). Phytochemical constituents and effects of aqueous root-bark extract of Ficus sycomorus L. (Moracaea) on muscular relaxation, anaesthetic and sleeping time on laboratory animals. African Journal Biotechnology, 8 (21), 6004-6006.

[36] Rao VSN, Santos FA, Sobreira TT, Souza MF, Melo CL and Silveira ER. (1997).Investigations on the gastroprotective and antidiarrhoeal properties of ternatin, a tetramethoxyflavone from Egletes viscosa. Planta Medica, 63, 146.

[37] Di carlo G, Autore G and Izzo AA. (1993). Inhibition of intestinal mobility and secretion by flavonoids in mice and rats: structure activity relationships. Journal Pharmacy and Pharmacology, 45, 1054-1059.

[38] Macauder PJ. (1986). Flavonoid affect acetylcholine, prostaglandin E and atigen mediated muscle contraction. Progres Clinical Biology Research, 213, 489-492.

[39] Capaaso F, Pinto A, Mascolo N, Autore G and Franco MP. (1988). Effects of flavonoids on PGE2-and LT4-induced contractions on the guinea pig isolated ileum. Pharmacology Research Commun, 20 (1), 201-202.

\section{How to cite this article}

Dosso K, Gboko AO, Attemene DSD, N'guessan BB and Yapo AP. (2020). The antispasmodic activity of ethanol extract of the stem bark of Piliostigma reticulatum Horscht D.C (Ceasalpiniaceae), and its dichloromethane fraction isolated. GSC Biological and Pharmaceutical Sciences, 11(1), 36-45. 